\title{
Sounds Better? Potential Implications of Obscure American Viticultural Areas to Consumers
}

\author{
Kar H. Lim (1) \\ Research Agricultural Economist, Economic Research Service, USDA, 805 Pennsylvania Ave, Kansas City, MO 64105, USA \\ ${ }^{\star}$ Corresponding author. Email: kar.lim@usda.gov
}

\begin{abstract}
The American Viticultural Area (AVA) allows designated wine regions to be created, marketed, and protected. But many of the now 248 AVAs may be meaningless to consumers. Are AVAs thus meritless? Can AVAs affect consumers despite low recognition? A choice experiment examines three appellations that are applicable to the same wine: New Jersey, USA; Pilesgrove, New Jersey; and Outer Coastal Plain (OCP)—a New Jersey AVA. The results show that consumers prefer OCP wines over the former alternatives, affirming the marketing potential of AVAs that omit state names. Nevertheless, AVA may have exploited consumers' lack of information.
\end{abstract}

Keywords: American Viticultural Area; appellation label policy; consumer preference; marketing of production origin; wine marketing;; willingness to pay

JEL codes: Q13; Q18; L66

\section{Introduction}

The number of wineries and vineyards in the United States has rapidly expanded. There were 9,654 wineries in 2018, up from about 1,000 in 2001; about 25,000 farms are engaging in viticulture (Bureau of Labor Statistics, 2018; Statista, 2019). While California accounts for $86 \%$ of U.S. wine production, more than half of the wineries are in other states, which are in general less famed than the Golden State in winemaking (Statista, 2019). Vintners and winemakers in these lessprestigious regions have used the American Viticultural Area (AVA) to establish designated wine regions (Chace and Smith, 2013). There are now 248 AVAs nationwide, noteworthy given that the first prestigious U.S. wine region, Napa, was relatively unremarkable until the 1960s (Alcohol and Tobacco Tax and Trade Bureau, 2020a; Taber, 2006). Nevertheless, the proliferation has prompted suggestions that AVAs are both confusing and meaningless, thus having no positive effect on consumer preference (Atkin and Johnson, 2010; Johnson and Bruwer, 2007b).

On the other hand, some winemakers argue that AVA's merit exists in a more nuanced way. In replacing a less-prestigious origin with an AVA, it causes consumers to overlook potentially negative quality that the less-prestigious origin implied, even though the AVA is itself unknown to consumers (Davidson, 2013; Smith, 2013). This claim, however, has received little attention in the literature.

If AVAs do little to stimulate consumer preference, it substantiates the opponents' claim, resources are wasted in creating meaningless identities of appellations. Conversely, if AVAs stimulate consumer preference, AVA is transformative in marketing terms, which enhances lessprestigious wine regions; AVA can thus provide economic development opportunities for the

(C) The Author(s) 2020. This is an Open Access article, distributed under the terms of the Creative Commons Attribution licence (http:// creativecommons.org/licenses/by/4.0/), which permits unrestricted re-use, distribution, and reproduction in any medium, provided the original work is properly cited. 
less-prestigious wine regions and potentially enhances land value in these rural regions (Cross, Plantinga, and Stavins, 2011b).

To shed more light on AVAs' merit, the impact of a New Jersey AVA on consumer willingness to pay (WTP) is examined with a choice experiment. From the results, consumers are willing to pay more for wines with the AVA label than other alternatives where "New Jersey" is noted. The respondents also rated the quality of the wine with the AVA label higher than wines from New Jersey. Given that these labels can apply to the same wine, the results suggest a spillover effectAVAs might be confounding consumers. In sum, this study supplies empirical insights, which can stimulate discussions to advance and safeguard AVA's policy.

\subsection{Background and Literature}

AVAs transform the experience attribute of American terroirs into a search attribute (Caswell and Mojduszka, 1996). The policy allows vintners, wineries, and sellers to capture the premium that the origin might generate. The importance of AVA is rooted in the concept of terroir, a belief that wine's quality is shaped by a place's soil, climate, and culture (Demossier, 2011; Gergaud and Ginsburgh, 2008; Gilbert, van der Lelie, and Zarraonaindia, 2014). Among the established AVAs are Fennville, Lancaster Valley, Bell Mountain, and High Valley-a dizzying array of names that hold little hints about their true geographical origins (Alcohol and Tobacco Tax and Trade Bureau, 2020a). Others like Napa Valley and Willamette Valley have become seals of quality to oenophiles around the world.

Terroirs have well-established links to the price of wines. Nine of the most expensive wines, averaging from $\$ 4,975$ to $\$ 19,327$, are from Côte de Nuits-a wine region in France; all American wines above $\$ 500$ per bottle originate from the Napa Valley (wine-searcher.com, 2018). Many studies have observed that wines' regions of origin generate price premium. For instance, small-scale cool-climate regional wines of Australia exhibit a higher price premium (Oczkowski, 1994). Wines from Pauillac, Pomerol, and St. Estephe are priced higher than the average Bordeaux wines (Cardebat and Figuet, 2004; Combris et al., 1997; Landon and Smith, 1997). Rioja and Duero produce higher-priced bottles among Spanish wines (Angulo et al., 2000). And Napa has a premium over other California, Washington, and most New World wines (Costanigro, McCluskey, and Mittelhammer, 2007; Delmas and Lessem, 2017; Schamel, 2009). Overall, the evidence that the place of origin is an important consideration in wine purchases is convincing.

Studies have examined various aspects of terroir. The geographical factor has been found to impact the prices of vineyards (Cross, Plantinga, and Stavins, 2011a, 2011b, 2017). Gokcekus and Finnegan (2017) found that sub-AVA elevates the prices of wines produced in Willamette County. Gergaud and Ginsburgh (2008) found that the impact of the natural endowment-which embodies terroir-has a negligible impact on wine quality; terroir affects the level of technological investment, which may cause quality to be misattributed to terroir; nevertheless, AVA may be needed to protect the technological investment. Overall, an argument exists for a place of origin trademark - to prevent infringement and to allow promotion of regional identity (U.S. Department of the Treasury, 2018a).

While often seen as such, AVAs are not seals of quality but strictly designations of places (Mendelson, 2016). The law stipulates that an AVA petition must meet the requirement of Distinguishing Features - which describes how a geographical area's climate, geological features, soils, and other features that may affect viticulture and make it distinctive (Office of the Federal Register, 1979). However, wine quality is not an essential requirement; the panel overseeing AVA petitions does not include experts in the evolving science of viticulture, enology, and other aspects of terroir (Mendelson, 2016). The AVA is unlike the French's System, where each Appellation d'origine Controlee (AOC) region specifies its production methods, minimum levels of alcohol, vine age, and other measurements (Munsie, 2002; Puckette, 2016). Therefore, if an AVA increases 
consumer preference and they are not rewarded with an elevated wine quality, it then raises the question if AVAs are merely marketing ploys, which may suggest an inherent flaw in the AVA policy.

Since the first AVA-Augusta in Missouri-was established in 1980, AVAs are now scattered across 33 states (U.S. Department of the Treasury, 2018a). Many of the AVAs are said to be unknown, uninformative, have no real premium to protect, and meaningless (Atkin and Newton, 2012; Gray, 2014; Johnson and Bruwer, 2007b; Mendelson, 2016). Johnson and Bruwer (2007a) suggest that the industry is "marketing unknown" by the rapid creation of AVA. The notion is supported by the observation that $55 \%$ of respondents have "no opinion of quality" for the Knight Valley AVA, but only 1\% professed to have no opinion of Sonoma County, when in fact Knight Valley is a premier partition of Sonoma County (Johnson and Bruwer, 2007b).

Consumer preference for appellations is influenced by subjective knowledge. For instance, German participants willing to pay more for the cheaper Passé Tout Grains AOC wine than the pricier Burgundy AOC wines, showing that knowledge and awareness moderate preference (Bazoche et al., 2013). Further, consumers expect better quality when the wine is presented with both a sub-AVA label and county, e.g., "Bennett Valley, Sonoma County," as opposed to just the sub-AVA label "Bennett Valley" alone (Bruwer and Johnson, 2010). Atkin and Newton (2012) show that consumers claimed to be more knowledgeable about "Sonoma County" than its sub-AVAs, despite that the sub-AVAs are more selective and prestigious. Atkin and Johnson (2010) observe that consumers use brands, regions, counties, vintage, and states more than AVAs as indicators of wine quality. These evidence cast doubts on the overall marketing value of AVAs; while some, such as Napa Valley, have established a reputation to be protected; most AVAs are likely unknown entities to consumers, which thus-in theory-hold little value as a marketing device, asssuming that consumers' knowledge is essential to create value.

\subsection{Objectives}

While regional identity is an important element in wine marketing, little is known if an obscure AVA can be beneficial as a marketing tool, and if so, at what cost in terms of Pareto efficiency. Without clarity on these questions, it is uncertain if AVAs are fulfilling its mandates to promote producers' and consumers' interests simultaneously. There are 19 pending petitions, indicating a strong and sustained interest in the industry for AVA, which highlights the value of this study (Alcohol and Tobacco Tax and Trade Bureau, 2020b).

With the goal to highlight the value created by a not-well-known AVA, this study investigates the effect of a New Jersey AVA on consumer preference. The results generate useful insights to illuminate the impact of an unknown AVA on consumers. Based on the results, relevant discussions about policy implications are carried out.

\section{Methods}

This study focuses on an AVA that fits the criteria of being relatively unknown and nested within a state with a traditionally weaker winemaking reputation, namely the Outer Coastal Plain (OCP) AVA, an AVA established in 2007, of Southern New Jersey (Office of the Federal Register, 2007).

In an ideal setting, we would regress the consumer preference of wines against AVAs-with perceived quality and other relevant factors controlled to ascertain the value of AVAs. Nevertheless, consumer preference is not directly observable; with 248 established AVAs and a general void of data about consumer preference of the AVAs, a comprehensive evaluation of all AVAs is relatively unreachable. A compromise in scope is necessitated by the challenge posed by the numerous AVAs in a controlled setting; many factors affect consumer preference for wines (Angulo et al., 2000; Lockshin and Corsi, 2012; Orth, McGarry Wolf, and Dodd, 2005). 
Our main hypotheses surround the impact of the OCP appellation label on consumer preference. We ask if consumers' WTP for the AVA label is systematically different from labels where "New Jersey" is denoted.

A choice experiment is used as it is easy to deploy on a wide sample, and it accommodates examination of multiple attributes in a controlled manner, fitting the purpose of this study (Hensher, Rose, and Greene, 2005). Furthermore, it has been applied in studies of consumer preference, including wine, which further justifies its use (Delmas and Lessem, 2017; Lusk, 2003; Meas et al., 2015; Perrouty, d'Hauteville, and Lockshin, 2006). The choice experiment is conducted online with a U.S.-wide sample of wine consumers. ${ }^{1}$

In the choice experiment, wines that differ according to a selected set of appellation labels, prices, and other attributes are generated (Figure 1). These alternatives of wines are distributed in choice sets; each choice set simulates a purchase situation, where respondents were asked to choose the most desirable alternatives within a choice set or to forego the purchase should the presented wines are not appealing. Note that these purchases are hypothetical; no actual money and products are exchanged. Consumer preference is inferred from the observed choices econometrically, where utility and WTP estimates are generated to gauge the economic impact of an AVA.

\section{Choice Experiment Design and Hypotheses}

The experiment features $750 \mathrm{ml}$ cabernet sauvignon-the most widely produced and consumed varietal in the United States; it is also the most widely planted varietal in the OCP region (Karlsson and Karlsson, 2018; Outer Coastal Plain Vineyard Association, 2020; Thach, 2015).

Six appellations labels are included: OCP; New Jersey, USA; Pilesgrove, New Jersey (Figure 1); California, USA; Napa Valley; and Product of USA (Table 1). These appellations will henceforth be referred to as OCP, NJ, Pilesgrove, California, Napa, and USA, where the italic denotes appellations.

A Southern New Jersey winery in Pilesgrove could use the first three labels. OCP allows the wine to be marketed by its AVA, where the state name is omitted. Whereas NJ and Pilesgrove advertise the state name. As the same wine can be marketed under these labels, any differences in WTP (ceteris paribus) thus result from the appellation labels, which teases out the effect of the AVA.

The design leverages OCP's fine wine production aspiration, which has been hindered by its state's weaker reputation (Smith, 2013; Thompson, 2018). In 2012, OCP wines competed against Bordeaux wines in a blind tasting, in a format similar to the Judgement of Paris that had propelled Napa into the first premier American wine region; the OCP wines were competitive, rank-sum tests found only 1 out of 12 OCP wines were deemed statistically inferior to the significantly higher-priced Bordeaux wines (Quandt et al., 2012).

Despite it, New Jersey has not been traditionally seen as a fine wine producing region. The state produces 2.7 million gallons of still wine in 2017 , which is $0.17 \%$ of the U.S. production by volume (U.S. Department of the Treasury, 2018b). Its winemaking reputation may have been somewhat negative. Media depictions demonstrate such sentiment; for example, George Taber, a renowned wine journalist, points to the state's history of "mass production of rotgut," referring to the sweet Welch-like wines that the state is known for (Davidson, 2013). The negative reputation was said to be an obstacle to the region's aspiring winemakers, prompting the creation of the OCP AVA as a means to shed the negative reputation of New Jersey wine (Chace and Smith, 2013; Davidson, 2013; Smith, 2013). The Wine Enthusiast magazine noted the rise of New Jersey wine quality, claiming that "New Jersey is ready for its time in the spotlight," but its subtext imply that the state's winemaking reputation is relatively lower (Thompson, 2018).

\footnotetext{
${ }^{1}$ The survey instrument was reviewed and approved by the institutional review board of the author's institution; no deception is used in the survey instrument.
} 


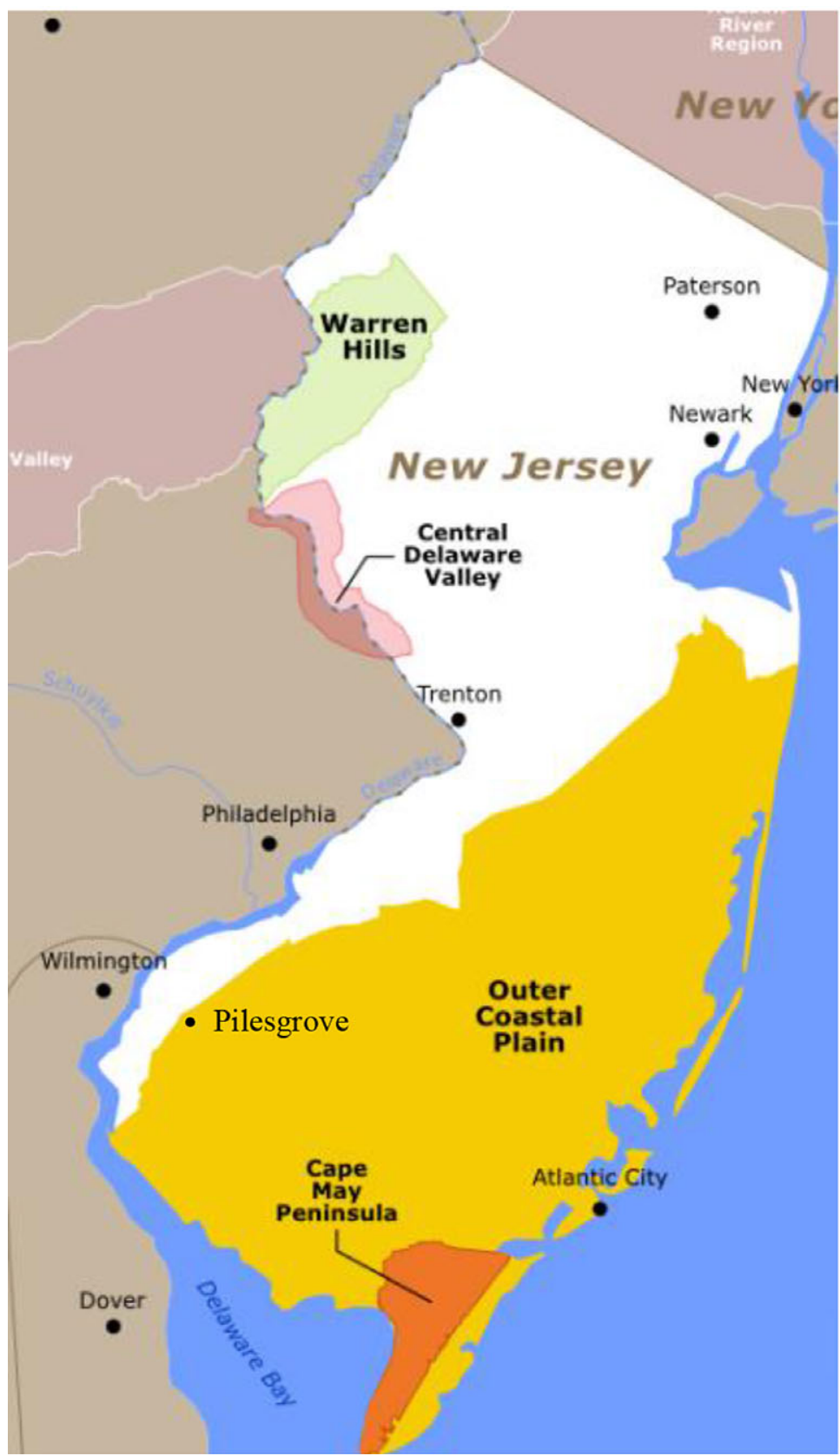

Figure 1. The map of Outer Coastal Plain and approximate location of Pilesgrove, New Jersey. Source: https://www.atwineries.com/wineries/united-states/new-jersey/outer-coastal-plain/

In this study, the degree to which OCP elevates the competitiveness of the New Jersey wine is a point of interest, specifically:

$$
H_{0}^{1}: W T P_{N J}-W T P_{O C P}=0
$$

Hypothesis 1 tests for the difference in WTP between the state appellation of New Jersey and $O C P$. Failure to reject the null indicates that the AVA is ineffective for price premium generation. 
Table 1. Attributes of the choice experiment

\begin{tabular}{|c|c|c|}
\hline Attributes & Levels & Appearance in the Choice Experiment \\
\hline \multirow[t]{6}{*}{ Appellations } & OCPa & Outer Coastal Plain \\
\hline & NJ & New Jersey, USA \\
\hline & Pilesgrove & Pilesgrove, New Jersey \\
\hline & California & California, USA \\
\hline & Napa & Napa Valley \\
\hline & USA & Product of USA \\
\hline \multirow[t]{2}{*}{ Organic } & No organic claim ${ }^{a}$ & [Blank] \\
\hline & Organic & Made with Organic Grapes \\
\hline \multirow[t]{2}{*}{ Sustainability } & No sustainability claima & [Blank] \\
\hline & Sustainable & $\begin{array}{l}\text { SUSTAINABLE } \\
\text { WINEMAKING }\end{array}$ \\
\hline \multirow[t]{4}{*}{ Price per bottle $(\$)$} & $\$ 7.99$ & \\
\hline & $\$ 10.99$ & \\
\hline & $\$ 13.99$ & \\
\hline & $\$ 16.99$ & \\
\hline
\end{tabular}

${ }^{\mathrm{a}}$ Base Categories of Dummy Variables, Prices are continuous.

If hypothesis 1 is rejected with $W T P_{N J}<W T P_{O C P}$, hypothesis 2 would suggest whether the premium could be due to the omission of "New Jersey" from the label,

$$
\begin{aligned}
& H_{0}^{2 a}: W T P_{\text {Pilesgrove }}-W T P_{O C P}=0 \\
& H_{0}^{2 b}: W T P_{\text {Pilesgrove }}-W T P_{N J}=0
\end{aligned}
$$

Pilesgrove is a town within the OCP; the Pilesgrove label thus represents a hypothetical sub-AVA of OCP in the vein of Calistoga AVA. ${ }^{2}$ Rejection of hypothesis 2 a with $W T P_{\text {Pilesgrove }}<W T P_{O C P}$, and the failure to reject hypothesis $2 \mathrm{~b}$ would suggest that respondents fail to recognize the geographical relations of these New Jersey-based appellations. Also, the inclusion of Pilesgrove could inform producers of the potential of such townships sub-AVA.

As a rational and fully informed consumer would not have significantly different WTP for the same wine, the pattern above would indicate that the assumption of perfect information is violated. Therefore, the WTP for OCP is likely stemming from consumer's lack of knowledge. This strategic use of AVA is reflected in real-world examples ${ }^{3}$ and as noted in Smith (2013).

As with all choice experiments, the number of required choice sets increases exponentially with the number of attributes, which renders a larger number of appellation labels impractical (Hensher et al., 2005). Nevertheless, the setting is sufficient to draw implications about marketing with relatively unknown AVAs.

In addition to appellations, the design also includes the Organic wine label and the Sustainable Winemaking label. These ecolabels are included to enhance realism, as it reflects wine sold in the

\footnotetext{
${ }^{2}$ https://www.wine-searcher.com/regions-calistoga.

${ }^{3}$ E.g., http://www.tastings.com/Product-Images/Wine/2018/9_23_2018/225337_fr.jpg;

http://www.heritagewinenj.com/wp-content/uploads/2016/06/chenin-blanc-heritage-vineyard-white-wine-650x650.jpg; https://ballymote.files.wordpress.com/2010/03/img_4820.jpg.
} 
market. ${ }^{4}$ The role of these increasingly popular labels to consumer preference has been discussed, where there remains a general lack of consensus regarding whether the labels appeal to consumers (Abraben, Grogan, and Gao, 2017; Delmas and Grant, 2014; Di Vita et al., 2019; Sogari et al., 2015; Waldrop, McCluskey, and Mittelhammer, 2017). This is despite that the market for organic wine has been expanding steadily, and various claims of sustainability have been increasingly used in marketing (Berghoef and Dodds, 2011; de La Hamaide and Denis, 2018; Ecolabel Index, 2019; Sogari, Mora, and Menozzi, 2016). Nevertheless, these ecolabels have been included here for realism, as the property is essential for data quality (Hensher et al., 2005; Louviere, Hensher, and Swait, 2000; Train, 2003). Additionally, the inclusion may minimize experimenter demand bias, which arises from respondents being overly focused on the research objectives (Sawyer, 1975).

Lastly, four levels of prices are used, which range from $\$ 7.99$ to $\$ 16.99$ in increments of $\$ 3.00$. These prices correspond to the $\$ 10$ per $750 \mathrm{ml}$ bottle after-tax mean retail price nationally (Bekkerman and Brester, 2019; Quackenbush, 2017; Wine and Vines, 2017). Bekkerman and Brester (2019) show that wine purchases above the price of $\$ 20$ represent only a smaller segment of the market. Thus, the price range is sensible given the goal of charting the consumer's preference at the mean level, rather than the narrower preferences of connoisseurs. The chosen range implies that the results might not reflect the market for higher-priced wines, where different evaluation criteria are likely used. Nevertheless, the proposed implementation satisfies our main objective, which is to understand how AVA affects most consumers.

The choice experiment features graphical representations of wine labels as depicted in Figure 2. In particular, the attributes appear as text on the wine labels, where the exact form is denoted in Table 1. In cases where a product is without Sustainable Winemaking or the organic grape claim, the space where the labels occupy are left blank, reflecting the common practice in the marketplace.

The study, as a positive analysis, intends to simulate the actual preference in the marketplace. Thus, respondents were not told the exact locations of the geographical labels and the definitions of Sustainable Winemaking and organic wine. This is so that consumers' preference for the attributes is not altered with the provision of information, as previous experiments have shown that such information can alter preference (Uchida et al., 2013).

To reduce hypothetical bias, i.e., respondents' tendency to inflate their stated WTP, a cheap talk script from Lusk (2003) is used in the study. The script has been shown to reduce hypothetical bias (Lusk, 2003; Tonsor and Shupp, 2011).

The choice sets are generated with D-efficiency criteria with the Partial Factorial Algorithm in JMP 13 (Crabbe and Vandebroek, 2012). The final design scores highly at 93.84\%, where all main effects can be estimated (Kuhfeld, 2010). The algorithm yields 24 unique choice profiles; the choice profiles are distributed into 48 choice sets (Hensher et al., 2005). Then, the choice sets are distributed into six blocks. Each respondent completes eight choice sets, which is below the threshold of fatigue (Czajkowski, Giergiczny, and Greene, 2014).

\section{Model}

A mixed logit (ML) model estimates the consumer preference. The model uses random coefficients to represent taste variation, allowing consumer WTP at different percentiles to be estimated (Train, 2003). Following the Random Utility Model,

$$
U_{i j t}=\alpha p_{i j t}+\boldsymbol{\mu} \mathbf{x}_{i j t}+\varepsilon_{i j t}
$$

where $U_{i j t}$ represents the utility level of respondent $i$ from the wine in the choice set $t$ 's alternative $j$. The variable $p$ represents the price level; its fixed coefficient avoids unrealistic WTP estimates implied by a random price coefficient (Hensher et al., 2005). The model sets

${ }^{4}$ Example of Organic Wine: http://www.princeofpinot.com/media/images/11_24/11_24-19.jpg;

Sustainable Winemaking: https://www.nzwine.com/media/2739/swnz-oct07.DbD1dg.jpg?width=300. 


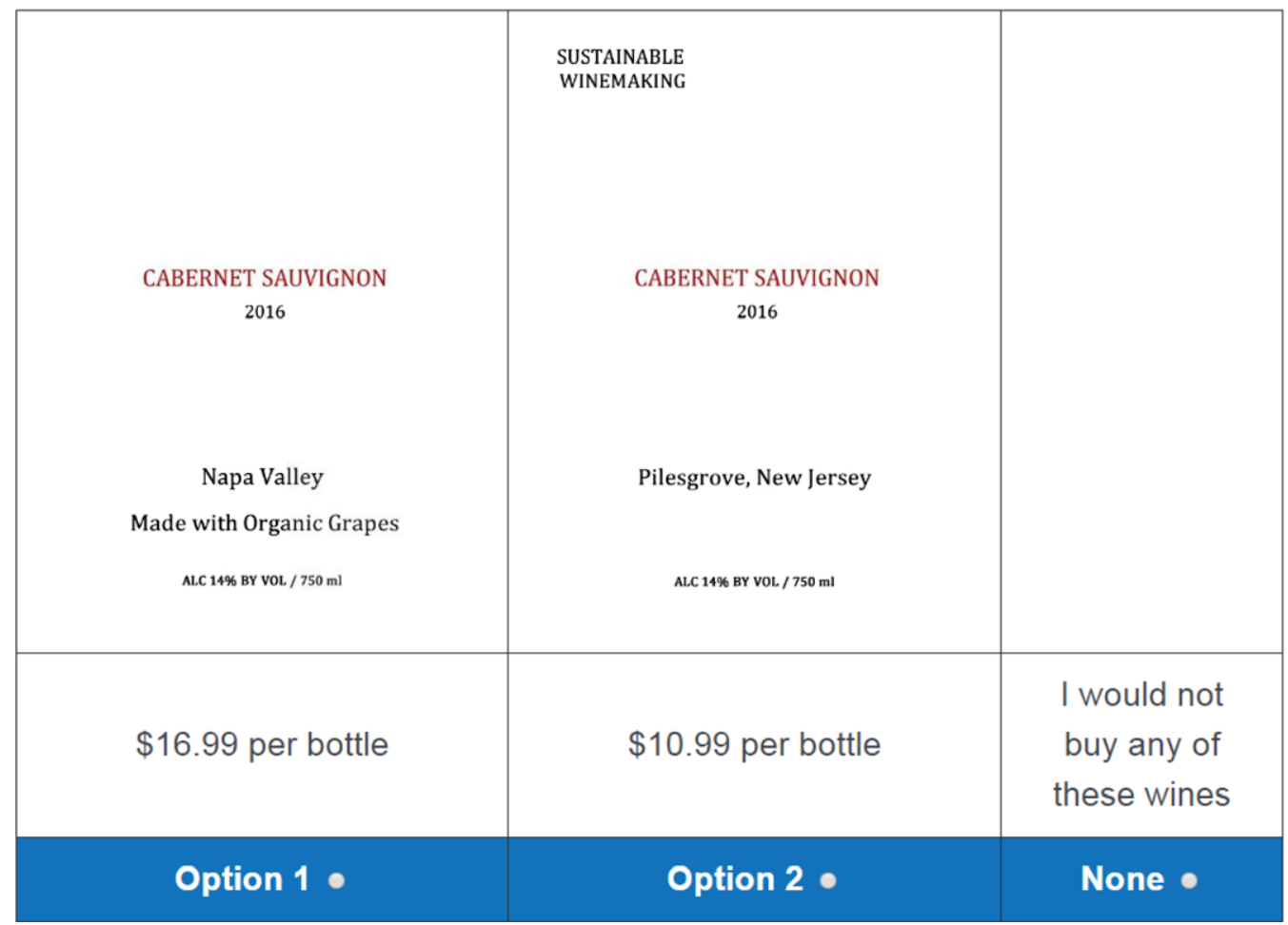

Figure 2. A sample choice set.

OCP, non-ecolabeled wines as the reference category. The dummy-coded vector $\mathbf{x}$ depicts the non-price attributes, $\mathbf{x}=$ [Opt Out, Organic, Sustainable, NJ, Pilesgrove, California, Napa, USA]. ${ }^{5}$ The coefficients associated with $\mathbf{x}$ are assumed to be normally distributed. Formally, $\boldsymbol{\mu} \sim \mathrm{N}\left(\boldsymbol{\beta}, \boldsymbol{\sigma}^{2}\right): \boldsymbol{\beta}$ corresponds to the mean; $\boldsymbol{\sigma}^{2}$ corresponds to the variance term that captures unobserved taste variation. The random coefficients are specified correlated to account for correlated taste among the attributes (Hensher et al., 2005).

The model's likelihood function involves an integral without a closed-formed solution. It is thus estimated with the Maximum Simulated Likelihood Method of STATA 15's Mixlogit module (Hole, 2007; Train, 2003). The results are simulated with 2000 Halton draws, where the stability of the estimates is established (Walker, 2002).

WTP estimates are derived from the ML model. Means of the WTP are calculated as $-\beta_{\text {attribute }} / \alpha$, and their standard errors are derived with the delta method (Hensher et al., 2005). To illustrate taste heterogeneity, the median and the 25th percentile of the WTP are simulated with the Krinsky and Robb method; specifically, 1,000 vectors of $\beta_{\text {attribute }}$ are generated, wherein the random coefficients' correlation is accounted (Hensher et al., 2005).

\section{Sampling}

Per the Tailored Design Method (Dillman, 2007), the survey was pilot-tested with a small panel of 18 respondents which include several experts of the method; the panel's comment was used to enhance the clarity of the survey. After this, the sampling was carried out online in November

\footnotetext{
${ }^{5}$ The opt-out (dummy) variable is set to one to represent the option of not buying in each choice set. The coefficient thus reflects a measurement of compensation variation for the consumers to forego consumption of the wines.
} 
Table 2. Summary statistics of the sample

\begin{tabular}{|c|c|c|}
\hline \multicolumn{3}{|c|}{ Glasses of wine consumed } \\
\hline $1-3$ glasses & $57.4 \%$ & \\
\hline 4-7 glasses & $28.7 \%$ & \\
\hline $7-10$ glasses & $9.7 \%$ & \\
\hline \multirow[t]{2}{*}{ More than 10 glasses } & $4.3 \%$ & \\
\hline & Sample & Population \\
\hline Female & $52.15 \%$ & $51.01 \%$ \\
\hline At least some college & $61.80 \%$ & $59 \%$ \\
\hline \multirow[t]{2}{*}{ Household income (\$) } & 51.780 .56 & 59,039 \\
\hline & $(29,041.46)$ & \\
\hline
\end{tabular}

Notes: $\mathrm{N}=1,047,8$ missing values in income data. Income of less than $\$ 10,000$ is coded as $\$ 10,000$; income of more than $\$ 100,000$ is coded as $\$ 105,000$; mid-points are used otherwise.

Source: Gender distribution (Kaiser Family Foundation, 2017).

2017 over a period of 21 days by Qualtrics, a professional survey company that also provided the survey software (Qualtrics, 2019). The average time taken to complete the survey is around $13 \mathrm{~min}$. The respondents, per common practice, were compensated with token gifts for their participation by the online panel company.

The study targets a national distributed sample, where it elicited responses from 1,047 American wine consumers. Those who claimed no consumption of wine per week on average are screened out of the sample; the mode and median glasses of wine per week are 1-3 glasses (Table 2). Slightly more than half of the sample is female (52.15\%). Most (62.2\%) have some college experience, which corresponds to the U.S. population statistics of 59\% (Ryan and Bauman, 2016). The reported mean household income is about $\$ 52,000$ - slightly lower than the median household income of $\$ 59,000$ (United States Census Bureau, 2017). The lower income is potentially due to the way the top income group is coded in this study (above $\$ 100,000$ is coded as $\$ 105,000)$. Overall, the sample corresponds reasonably to the characteristics of the U.S. population. Additionally, the sample also corresponds reasonably to the range of demographic characteristic noted in other reports (Thach and Camillo, 2018; Wine Intelligence, 2018); in particular, the education profile matches those reported in Thach and Camillo (2018) and the gender distribution to Wine Intelligence (2018); higher income than this study is noted in both reports, which again may be due to the way our data is categorized.

We evaluate if the results is skeewed by the preference of New Jersey residents, particularly if they exhibit a strong preference for OCP. Residents of New Jersey make up 3.4\% of the sample, which tracks the population statistics (United States Census Bureau, 2017). To verify the potential bias, a ML model is tested. This model includes additional terms, where a dummy variable indicating that the respondent is New Jersey resident interacts with the appellation variables (Appendix Table A1). The results show that none of the interaction terms is statistically significant, indicating that the collective preference for the appellations of New Jersey residents is not different from the whole sample. Thus, the concern of the bias is minimal.

\section{Results}

For a fuller context, the respondents' perceived quality of wines is included as a preview. The ratings are tabulated in Table $3 .^{6}$ As expected, Napa implies the highest quality for the respondents; more than

\footnotetext{
${ }^{6}$ California was omitted due to a coding error in the survey instrument.
} 
Table 3. Quality rating by appellations

\begin{tabular}{lccccccc}
\hline & 1 & 2 & 3 & 4 & 5 & Mean & Standard deviation \\
\hline Product of USA & $4.2 \%$ & $9.2 \%$ & $54.2 \%$ & $22.7 \%$ & $9.7 \%$ & 3.25 & 0.90 \\
\hline Napa Valley, USA & $1.2 \%$ & $4.4 \%$ & $19.5 \%$ & $46.6 \%$ & $28.4 \%$ & 3.97 & 0.87 \\
\hline New Jersey, USA & $4.5 \%$ & $20.7 \%$ & $49.2 \%$ & $19.0 \%$ & $6.6 \%$ & 3.02 & 0.92 \\
\hline Pilesgrove, New Jersey & $4.7 \%$ & $21.6 \%$ & $49.4 \%$ & $18.4 \%$ & $5.9 \%$ & 2.99 & 0.91 \\
\hline Outer Coastal Plain, USA & $2.5 \%$ & $13.2 \%$ & $50.8 \%$ & $25.7 \%$ & $7.8 \%$ & 3.23 & 0.86 \\
\hline
\end{tabular}

Notes: $N=1,047.1=$ far below average; 2 = somewhat below average; $3=$ average; $4=$ somewhat above average; $5=$ far above average. The question is worded as: "Based on your intuition, what do these tell about the wine quality?"

$70 \%$ of the sample perceives that the appellation implies higher than average quality. The ratings given to USA and OCP are statistically equivalent $(P=0.64$; mean [USA] $=$ mean $[\mathrm{OCP}])$, but lower than the ratings for Napa $(P<0.001$ in both cases). However, in this setting, "USA" was attached to "Outer Coastal Plain," which might have elevated the ratings given to OCP. The ratings given to NJ and Pilesgrove are the lowest, where the mean scores are around the "average" rating; $t$-tests suggest that both are rated lower than $O C P(P<0.001$ in both cases). These results thus suggest that $O C P$ is perceived as better than $N J$ and Pilesgrove. While the data are not directly available, the respondents are unlikely to mistake $O C P$ as a California appellation, since the percentage of respondents who rated $O C P$ as being above average is vastly less than the percentage who rated Napa highly; also, Californian wine, in general, is perceived positively (Orth et al., 2005).

We analyze ratings by the subsample of New Jersey residents. The main distinction is that NJ and Pilesgrove receive higher ratings than the full sample, where both are statistically equivalent to $U S A$. The ratings given to the pair are also higher than $O C P(P=0.013$ for mean $[N J]>$ mean $[O C P] ; P=0.06$ for mean [Pilesgrove] $>$ mean $[O C P])$. The state's residents value products with the "New Jersey" relatively higher than the full sample. Further, the lower relative rating of $O C P$ suggests that New Jersians are uninformed since the three New Jersey appellations are closely related.

\section{Econometric Estimates}

The ML model converges with McFadden $R^{2}$ of $26 \%$ (Table 4) (Hensher et al., 2005). The price coefficient $(\alpha)$ is negative $(P<0.01)$ as expected. The opt-out coefficient $\left(\beta_{\text {opt-out }}\right)$ is negative $(P<0.01)$ - a sign of successful sample screening, as the respondents are interested in the products. The positive coefficient $\left(\beta_{\text {organic }}\right)$ indicates that organic is a preferred attribute, although at the mean level, consumers are indifferent toward sustainable winemaking. ${ }^{7}$ Six of eight diagonal elements of the random coefficient's Cholesky matrix are statistically significant, suggesting substantial taste heterogeneity toward the attributes (Hensher et al., 2005). A joint test that all the tested appellations are equivalent to $O C P$ is rejected $(P<0.01)$, indicating that the origin labels affect consumer choice.

The utility estimates infer a hierarchy of appellations. Napa is the most preferred, followed by California; their difference is statistically significant $(P<0.01)$, suggesting $N a p a$ is more preferred among the two. The Product of USA comes third. OCP, the omitted category, ranks fourth. The last pair is the New Jersey and Pilesgrove wines, where they are not statistically different $(P=0.86)$.

\footnotetext{
${ }^{7}$ Respondents may not be informed or convinced about "Sustainable Winemaking." The insignificant ecolabel coefficient reflects previous findings. Readers can refer to Delmas and Lessem (2017), as well as Lim and Reed (2020)—the companion publication of this paper, for more discussions.
} 
Table 4. Mixed Logit (ML) estimates

\begin{tabular}{|c|c|c|c|c|}
\hline \multirow{3}{*}{ Price } & \multicolumn{2}{|c|}{ Main coefficients } & \multicolumn{2}{|c|}{ Standard deviation } \\
\hline & -0.23 & $\star \star \star$ & \multicolumn{2}{|c|}{ FIXED } \\
\hline & $(0.01)$ & & & \\
\hline \multirow[t]{2}{*}{ Opt out } & -4.51 & $\star \star \star *$ & 8.70 & 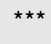 \\
\hline & $(0.17)$ & & $(0.96)$ & \\
\hline \multirow[t]{2}{*}{ Organic } & 0.25 & 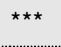 & 0.91 & 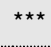 \\
\hline & $(0.06)$ & & $(0.15)$ & \\
\hline \multirow[t]{2}{*}{ Sustainable } & 0.05 & & 0.23 & $\star \star$ \\
\hline & $(0.05)$ & & $(0.09)$ & \\
\hline \multirow[t]{2}{*}{ NJ } & -0.24 & $\star \star \star *$ & 1.35 & $\star \star \star *$ \\
\hline & $(0.09)$ & & $(0.36)$ & \\
\hline \multirow[t]{2}{*}{ Pilesgrove } & -0.26 & $\star \star \star *$ & 0.70 & $\star \star \star *$ \\
\hline & $(0.08)$ & & $(0.22)$ & \\
\hline \multirow[t]{2}{*}{ Napa } & 1.05 & 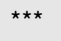 & 1.19 & 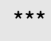 \\
\hline & $(0.08)$ & & $(0.31)$ & \\
\hline \multirow[t]{2}{*}{ California } & 0.79 & $\star \star \star \star *$ & 0.42 & $\star * \star *$ \\
\hline & $(0.07)$ & & $(0.15)$ & \\
\hline \multirow[t]{2}{*}{ USA } & 0.28 & $\star \star \star *$ & 0.39 & $* *$ \\
\hline & $(0.07)$ & & $(0.17)$ & \\
\hline Log-likelihood & & & $-6,802.19$ & \\
\hline McFadden $R^{2}$ & & & 0.2607 & \\
\hline \multicolumn{5}{|l|}{ F-tests: } \\
\hline $\begin{array}{l}\beta_{\mathrm{NJ}}=0 \\
\beta_{\text {California }}=0 \\
\beta_{\text {Napa }}=0 \\
\beta_{\text {Pilesgrove }}=0 \\
\beta_{\text {USA }}=0\end{array}$ & $\chi^{2}(5)=299.91$ & $\star \star \star$ & & \\
\hline$\beta_{\text {Napa }}=\beta_{\text {California }}$ & $\chi^{2}(1)=13.88$ & $\star \star \star$ & & \\
\hline$\beta_{\mathrm{NJ}}=\beta_{\text {Pilesgrove }}$ & $\chi^{2}(1)=0.03$ & & & \\
\hline
\end{tabular}

Notes: Single, double, and triple asterisks $\left({ }^{*},{ }^{* \star},{ }^{* \star *}\right)$ indicate statistical significance at the $10 \%, 5 \%$, and $1 \%$ level. Standard errors in brackets.

These estimates largely fit the expected hierarchy of appellations, and our key interest is that the utility associated with $O C P$ is significantly different from all other examined appellations.

With the negative $W T P_{N J}(P<0.01)$, consumers prefer $O C P$ over the NJ state appellation (Table 5). The average consumer is willing to pay about $\$ 1.00$ more for the OCP wines. And $25 \%$ of the consumers are willing to pay $\$ 4.00$ per bottle more for the OCP wines (Table 5). Thus, the result supports the benefit of switching from state appellation to the AVA.

$W T P_{\text {Pilesgrove }}$ is statistically equivalent to $W T P_{N J}(P=0.86)$, but it is lower against $W T P_{O C P}$ $(P<0.01)$. Consumers are indifferent between both wines explicitly noted as from New Jersey, despite one indicates the township and another only the state. However, OCP elicited a higher WTP than Pilesgrove when both could have been identical wines. Given that the state of origin 
Table 5. WTP derived from the ML model

\begin{tabular}{|c|c|c|c|c|c|}
\hline & \multirow[b]{2}{*}{ Hypotheses } & \multicolumn{2}{|c|}{ Mean (\$) } & \multicolumn{2}{|c|}{ Percentile (\$) } \\
\hline & & WTP & & 25th & 75th \\
\hline \multirow[t]{2}{*}{ Opt out } & & -19.97 & $\star \star * *$ & -29.11 & -11.29 \\
\hline & & $(0.68)$ & & & \\
\hline \multirow[t]{2}{*}{ Organic } & & 1.13 & 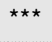 & -1.85 & 4.05 \\
\hline & & $(0.25)$ & & & \\
\hline \multirow[t]{2}{*}{ Sustainable } & & 0.20 & & -1.21 & 1.69 \\
\hline & & $(0.21)$ & & & \\
\hline \multirow[t]{2}{*}{ NJ } & $\mathrm{H}^{1}$ & -1.05 & 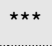 & -4.32 & 2.35 \\
\hline & & $(0.40)$ & & & \\
\hline \multirow[t]{2}{*}{ Pilesgrove } & $\mathrm{H}^{2 \mathrm{a}}$ & -1.13 & 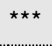 & -3.75 & 1.24 \\
\hline & & $(0.35)$ & & & \\
\hline \multirow[t]{2}{*}{ New Jersey_Pilesgrove } & $\mathrm{H}^{2 b}$ & 0.08 & & & \\
\hline & & $(0.42)$ & & & \\
\hline \multirow[t]{2}{*}{ California } & & 3.48 & $\star \star \star$ & 1.57 & 5.53 \\
\hline & & $(0.32)$ & & & \\
\hline \multirow[t]{2}{*}{ Napa } & & 4.65 & $\star \star \star *$ & 1.43 & 7.92 \\
\hline & & $(0.37)$ & & & \\
\hline \multirow[t]{2}{*}{ USA } & & 1.25 & $\star \star \star *$ & -0.42 & 3.19 \\
\hline & & $(0.31)$ & & & \\
\hline \multirow[t]{2}{*}{ California-NJ } & & 4.53 & $\star \star \star \star$ & & \\
\hline & & $(0.42)$ & & & \\
\hline \multirow[t]{2}{*}{$\mathrm{Napa}-\mathrm{NJ}$} & & 5.71 & $\star \star \star *$ & & \\
\hline & & $(0.47)$ & & & \\
\hline
\end{tabular}

Notes: Single, double, and triple asterisks $\left({ }^{*},{ }^{* \star},{ }^{* \star *}\right)$ indicate statistical significance at the $10 \%, 5 \%$, and $1 \%$ level. Standard errors are calculated with the delta method. Percentile is calculated by Krinsky and Robb simulation that account for the correlated random coefficients. Standard errors in brackets.

is omitted from the OCP label, the omission may have contributed to the preference of OCP wines, as previously observed.

The OCP label affects competitiveness. There are substantial differences in WTP between Napa and California wines to New Jersey wines ( $\$ 5.71$ and $\$ 4.53$, respectively). The OCP label lowers the gaps considerably. Switching from New Jersey to OCP reduces the gaps by $\$ 1.05$ on average. The effect is pronounced at the niche level; $25 \%$ of the consumers are willing to pay only around $\$ 1.50$ less for the OCP wine than the wines from Napa and California. These results again support that the AVA label is competitiveness enhancing.

Finally, the average consumer prefers Product of USA to OCP, for which they are willing to pay $\$ 1.25$ higher. The preference is in line with observations that the average consumer would rely more on broader and more recognizable appellation than AVA (Atkin and Johnson, 2010; Atkin and Newton, 2012; Bruwer and Johnson, 2010; Johnson and Bruwer, 2007b). However, the preference is not generalized to the whole sample; the WTP at the 25th percentile suggests 
that consumers are willing to pay more $(\$ 0.42)$ for OCP than for the USA-labeled wine. The contrast may be due to the differences in consumers' characteristics, where the niche consumers may make use of AVAs more as a quality indicator. A question is nevertheless raised if denoting the American origin of an AVA label could be advantageous-e.g., OCP, USA - which future studies tailored for this purpose can verify.

\section{Discussion and Policy Recommendations}

To the question "do AVA labels affect consumer preference," the answer from the results is a resounding yes. The level of preference is systematically different by appellation labels. Appellations serve as a quality cue; Napa is sought after, New Jersey wines labeled as such are less desirable. The preference for $O C P$ is stronger on average than the preference for $N J$ and Pilesgrove. These observations bolster the position that the AVA may be elevating consumer preference for the New Jersey wines. The answer to should AVAs be adopted, however, is more nuanced.

The Cumulative Prospect Theory explains the observed behavior intuitively. In nutshell, the theory suggests that risk attitude is outcome dependent (Tversky and Kahneman, 1992). In context, the perception ratings imply buying New Jersey wines is viewed as a probable bad outcome. The theory observes that people are more risk-seeking when a bad outcome is more likely, i.e., in the choice between New Jersey wines and $O C P, O C P$ 's unknown quality is more appealing. The strategy of "don't say it's from New Jersey" thus has its merit (Smith, 2013).

Nevertheless, there may be exceptions especially for wineries targeting local consumers. Residents of New Jersey have given higher ratings for the wines where the state name is mentioned than from OCP. ${ }^{8}$ The discrepancy shows that consumers can be uninformed even if the AVA is within one's home state. When the primary market is local, the wineries should instead use appellation labels with the state name, as responding to consumers' desire to support local farmers and businesses may be more rewarding (Darby et al., 2008; Di Vita et al., 2019; Lim and Hu, 2016; Martinez et al., 2010).

Also, the strategy to adopt AVA can be less appealing in the short term. As the results show, the generic American appellation may appeal to certain segments of consumers. Nevertheless, adopting the American appellation would forego the potential to forge a regional identity, where the success - as Napa and Willamette Valley show_can bring about long-term rewards (Cross et al., 2011b; Hira and Swartz, 2014).

While the analysis shows a potential benefit, it is insufficient to claim that all AVAs are preferred over state appellations. The effect likely depends on the quality projected by the specific AVA, which is dependent on the semantics. Also, the context of our analysis is specific to New Jersey; while many states' winemaking reputation may be comparable, others such as Washington and Oregon have advanced considerably in recent years. Additionally, the validity of our findings could be verified against reveal preference data in future studies. Interested winemakers should carefully gauge the cost-benefit of their proposed AVA, as well as the winemaking reputation of their state, of which our analysis may serve as a template.

The fact that AVA influences consumer preference shows that the appellation label could be valuable for wineries to shape their regional identity. This suggests that AVA should be viewed as a common asset, of which the Collective Action Theory can be a useful guide (Ostrom, 1998). Wineries within an AVA can work collaboratively to increase the reputation of an AVA by sharing production knowledge and resource (Hira and Swartz, 2014; Johnson and Bruwer, 2007b). The reward for an improved quality image of an AVA could be immense; reputation increases of even a subset of wineries within an AVA may feed into the appellation's wine prices, especially for wines that are in the lower price ranges (Costanigro, McCluskey, and Goemans, 2010).

\footnotetext{
${ }^{8}$ The higher rating does not result in statistically higher preference, see Appendix Table A1.
} 
Conversely, the AVA should not be abused as a tool to deceive; in repeated purchases, consumer experience unveils the mystique of an unknown AVA. After this, the AVA may serve either as a signal of good or bad quality contingent on consumers' experience (Steenkamp, 1990). AVAs should be viewed as a tool for aspiring wine regions to gain competitiveness and to form a regional brand reputation, but it should not be viewed as a substitute for long-term improvements in quality.

The Mississippi Delta AVA serves as a testament that AVA is not a panacea, the AVA-established in 1984-has failed to jump-start production volume of the AVA, which covers northwestern Mississippi, parts of Tennessee, and Louisiana (Appellation America, n.d.). While AVA appears a promising but supplemental tool, quality improvement should remain the top priority for aspiring wine regions.

Noteworthily, the results unveil an inherent conflict in the dual purposes of AVA in simultaneously promoting producer interest and consumer interest. AVA can be valuable as a marketing tool, but it can arguably harm consumers when pursued as a disguise of poor wine quality. If the decision to use AVA rests upon disguising a negative with an unknown, whether the practice constitutes exploitation of consumers' lack of information is concerning. Parallels can be drawn from the "Natural" label, which is misunderstood by consumers and yet effective as a marketing tool (Abrams, Meyers, and Irani, 2010). The issue should be critically examined in future research and policy debates, especially on what AVA implies to consumers.

If it is deemed that consumers are misguided by AVAs, this deleterious effect could be addressed with a mandate of full disclosure. This suggestion follows the calls from previous studies that a more meaningful, broader regional name should be attached to an AVA label (Atkin and Johnson, 2010; Johnson and Bruwer, 2007a, 2007b; McCutcheon, Bruwer, and Li, 2009). Such disclosure can reduce the information gap and enable consumers to make better-informed decisions.

Also, the ethical issue may be resolved if AVA is elevated to an official seal of quality. Such a quality stipulation might be necessary to legitimatize and preserve the health of the AVA system; consumers who are repeatedly disappointed by AVA could conceivably discount the designation as merely a marketing ploy. To prevent the devaluation of AVA, quality standards can be established such that all products under an AVA must meet the distinctive characteristics of terroirsuch as sugar content of grapes, the alcohol content of wines, to the molecular characteristics of an appellation (Mendelson, 2016). The change involves production guidelines, putting the AVA more in line with the French AOC system, which many see as more substantive than the present set-up of the AVA system (Johnson and Bruwer, 2007a; Mendelson, 2016).

\section{Conclusions}

Many AVAs have been created, and more will likely be created, despite the substantial costs of such endeavor (Alcohol and Tobacco Tax and Trade Bureau, 2020b; Johnson and Bruwer, 2007b). Yet relatively little is known about the effect of an AVA to a less renowned wine region. This study examines consumer WTP of such AVAs, using the OCP of New Jersey as an example.

The OCP AVA generates a higher WTP, in general, vis-à-vis its state appellation. Further, the AVA label reduces the WTP gap between the New Jersey wines to Californian and Napa wines, suggesting that the AVA label adds a competitive advantage. Cumulative Prospect Theory may explain the preference of an unknown AVA over a less-prestigious appellation, as consumers are risk-seeking when facing a probable bad outcome (Tversky and Kahneman, 1992).

AVA may be a double-edged sword. Its dual mandate may be increasingly fractious with ever more AVAs. If consumers deem as deception the intention to disguise an unglamorous wine origin with an AVA, the marketing benefits come at a cost to consumers. Whether the AVA system can truly benefit producers and consumers in all situations must be further scrutinized. 


\section{References}

Abraben, L.A., K.A. Grogan, and Z. Gao. “Organic Price Premium or Penalty? A Comparative Market Analysis of Organic Wines from Tuscany.” Food Policy 69(2017):154-65.

Abrams, K.M., C.A. Meyers, and T.A. Irani. "Naturally Confused: Consumers' Perceptions of All-Natural and Organic Pork Products." Agriculture and Human Values 27,3(2010):365-74.

Alcohol and Tobacco Tax and Trade Bureau. "Established AVAs," 2020a. Internet site: https://www.ttb.gov/wine/ established-avas (Accessed June 23, 2020).

Alcohol and Tobacco Tax and Trade Bureau. "List of Pending American Viticultural Areas Petitions," 2020b. Internet site: https://www.ttb.gov/wine/list-of-pending-american-viticultural-areas-petitions (Accessed June 23, 2020).

Angulo, M.A., M.J. Gil, A. Gracia, and M. Sánchez. "Hedonic Prices for Spanish Red Quality Wine." British Food Journal 102,7(2000):481-93.

Appellation America. "Mississippi Delta (AVA)," 2020. Internet site: http://wine.appellationamerica.com/wine-region/ Mississippi-Delta.html (Accessed June 24, 2020).

Atkin, T., and R. Johnson. "Appellation as an Indicator of Quality." International Journal of Wine Business Research 22,1(2010):42-61.

Atkin, T., and S. Newton. "Consumer Awareness and Quality Perceptions: A Case for Sonoma County Wines." Journal of Wine Research 23,2(2012):155-71.

Bazoche, P., P. Combris, E. Giraud-Héraud, and J.-B. Traversac. "Willingness to Pay for Appellation of Origin: Results of an Experiment with Pinot Noir Wines in France and Germany." Wine Economics. E. Giraud-Héraud and M.C. Pichery, eds. London: Palgrave Macmillan, 2013.

Bekkerman, A., and G.W. Brester. "Don't Judge a Wine by Its Closure: Price Premiums for Corks in the US Wine Market." Journal of Wine Economics 14,1(2019):3-25.

Berghoef, N., and R. Dodds. "Potential for Sustainability Eco-Labeling in Ontario's Wine Industry." International Journal of Wine Business Research 23,4(2011):298-317.

Bruwer, J., and R. Johnson. "Place-Based Marketing and Regional Branding Strategy Perspectives in the California Wine Industry.” Journal of Consumer Marketing 27,1(2010):5-16.

Bureau of Labor Statistics. “Employment in Wineries Up 153 Percent from 2001 to 2017,” TED: The Economics Daily, 2018. Internet site: https://www.bls.gov/opub/ted/2018/employment-in-wineries-up-153-percent-from-2001-to-2017.htm (Accessed March 7, 2019).

Cadebat, J.-M., and J.-M. Figuet. "What Explains Bordeaux Wine Prices?" Applied Economics Letters 11,5(2004):293-6.

Caswell, J.A., and E.M. Mojduszka. "Using Informational Labeling to Influence the Market for Quality in Food Products." American Journal of Agricultural Economics 78,5(1996):1248-53.

Chace, Z., and R. Smith. "Episode 444: New Jersey Wine," Planet Money, 2013. Internet site: https://www.npr.org/templates/ transcript/transcript.php?storyId=174430619 (Accessed May 8, 2016).

Combris, P., S. Lecocq, and M. Visser. "Estimation of a Hedonic Price Equation for Bordeaux Wine: Does Quality Matter?" The Economic Journal 107,441(1997):390-402.

Costanigro, M., J.J. McCluskey, and C. Goemans. "The Economics of Nested Names: Name Specificity, Reputations, and Price Premia." American Journal of Agricultural Economics 92,5(2010):1339-50.

Costanigro, M., J.J. McCluskey, and R.C. Mittelhammer. "Segmenting the Wine Market Based on Price: Hedonic Regression When Different Prices Mean Different Products.” Journal of Agricultural Economics 58,3(2007):454-66.

Crabbe, M., and M. Vandebroek. "Using Appropriate Prior Information to Eliminate Choice Sets with a Dominant Alternative from D-efficient Designs." Journal of Choice Modelling 5,1(2012):22-45.

Cross, R., A.J. Plantinga, and R.N. Stavins. “The Value of Terroir: Hedonic Estimation of Vineyard Sale Prices.” Journal of Wine Economics 6,1(2011):1-14.

Cross, R., A.J. Plantinga, and R.N. Stavins. "What is the Value of Terroir?" American Economic Review 101,3(2011):152-6.

Cross, R., A.J. Plantinga, and R.N. Stavins. "Terroir in the New World: Hedonic Estimation of Vineyard Sale Prices in California." Journal of Wine Economics 12,3(2017):282-301.

Czajkowski, M., M. Giergiczny, and W.H. Greene. "Learning and Fatigue Effects Revisited: Investigating the Effects of Accounting for Unobservable Preference and Scale Heterogeneity." Land Economics 90,2(2014):324-51.

Darby, K., M.T. Batte, S. Ernst, and B. Roe. "Decomposing Local: A Conjoint Analysis of Locally Produced Foods." American Journal of Agricultural Economics 90,2(2008):476-86.

Davidson, A. "How New Jersey Could Make Itself the New Napa," The New York Times, 2013. Internet site: https://www. nytimes.com/2013/03/17/magazine/is-new-jersey-the-new-napa.html (Accessed May 25, 2019).

de La Hamaide, S., and P. Denis. “Organic Wine Market Growing Fast But to Remain Niche: Study,” Reuters, 2018. Internet site: https:/www.reuters.com/article/us-wine-organic/organic-wine-market-growing-fast-but-to-remain-niche-study-idUSKCN1NS149 (Accessed February 21, 2019).

Delmas, M.A., and L.E. Grant. "Eco-Labeling Strategies and Price-Premium the Wine Industry Puzzle.” Business \& Society 53,1(2014):6-44. 
Delmas, M.A., and N. Lessem. "Eco-Premium or Eco-Penalty? Eco-Labels and Quality in the Organic Wine Market." Business \& Society 56,2(2017):318-56.

Demossier, M. "Beyond Terroir: Territorial Construction, Hegemonic Discourses, and French Wine Culture." Journal of the Royal Anthropological Institute 17,4(2011):685-705.

Dillman, D.. Mail and Internet Surveys: The Tailored Design Method, 2nd ed. Hoboken, NJ: John Wiley \& Sons, 2007.

Di Vita, G., G. Pappalardo, G. Chinnici, G. La Via, and M. D’Amico. "Not Everything Has Been Still Explored: Further Thoughts on Additional Price for the Organic Wine." Journal of Cleaner Production 231(September 2019):520-528.

Ecolabel Index. Internet site: http://www.ecolabelindex.com/ (Accessed November 6, 2019).

Gergaud, O., and V. Ginsburgh. "Natural Endowments, Production Technologies and the Quality of Wines in Bordeaux. Does Terroir Matter?” The Economic Journal 118,529(2008):142-57.

Gilbert, J.A., D. van der Lelie, and I. Zarraonaindia. "Microbial Terroir for Wine Grapes." Proceedings of the National Academy of Sciences 111,1(2014):5-6.

Gokcekus, O., and C.M. Finnegan. "Price Effects of Establishing a New Sub-AVA within Oregon"s Willamette Valley AVA." Journal of Wine Economics 12,4(2017):345-53.

Gray, W. "California AVAs: Too Much of a Good Thing," Wine-Searcher, 2014. Internet site: https://www.wine-searcher. $\mathrm{com} / \mathrm{m} / 2014 / 10 /$ california-avas-too-much-of-a-good-thing (Accessed December 7, 2018).

Hensher, D.A., J.M. Rose, and W.H. Greene Applied Choice Analysis: A Primer. New York: Cambridge University Press, 2005.

Hira, A., and T. Swartz. "What Makes Napa Napa? The Roots of Success in the Wine Industry." Wine Economics and Policy 3,1(2014):37-53.

Hole, A. "Fitting Mixed Logit Models by Using Maximum Simulated Likelihood." Stata Journal 7,3(2007):388.

Johnson, R., and J. Bruwer. "Regional Brand Image and Perceived Wine Quality: The Consumer Perspective." International Journal of Wine Business Research 19,4(2007a):276-97.

Johnson, R., and J. Bruwer. "The Balancing Act between Regionality and American Viticultural Areas (AVAs)." Journal of Wine Research 18,3(November 2007b):163-72.

Kaiser Family Foundation. "Population Distribution by Sex." Internet site: https://www.kff.org/other/state-indicator/ distribution-by-gender/ (Accessed April 4, 2018).

Karlsson, P., and B. Karlsson. “The 10 Most Popular Wine Grapes in the U.S.," Forbes, 2018. Internet site: https://www. forbes.com/sites/karlsson/2018/06/08/the-most-popular-wine-grapes-in-the-us-chardonnay-and-cabernet-the-full-top10-list/ (Accessed August 7, 2017).

Kuhfeld, W.F. Marketing Research Methods in SAS Experimental Design, Choice, Conjoint, and Graphical Techniques. Cory, NC: SAS Institute Inc, 2010.

Landon, S., and C.E. Smith. "The Use of Quality and Reputation Indicators by Consumers: The Case of Bordeaux Wine." Journal of Consumer Policy 20,3(1997):289-323.

Lim, K.H., and W. Hu. "How Local Is Local? A Reflection on Canadian Local Food Labeling Policy from Consumer Preference." Canadian Journal of Agricultural Economics 64,1(2016):71-78.

Lim, K.H., and M. Reed. “Do Ecolabels Cheapen Wines?” Journal of Cleaner Production 245(2020):118696.

Lockshin, L., and A.M. Corsi. "Consumer Behaviour for Wine 2.0: A Review Since 2003 and Future Directions." Wine Economics and Policy 1,1(2012):2-23.

Louviere, J.J., D.A. Hensher, and J.D. Swait. Stated Choice Methods: Analysis and Applications. New York: Cambridge University Press, 2000.

Lusk, J.L. "Effects of Cheap Talk on Consumer Willingness-to-Pay for Golden Rice." American Journal of Agricultural Economics 85,4(2003):840-856.

Martinez, S., M. Hand, M. Da Pra, S. Pollack, K. Ratson, T. Smith, and C. Newman. Local Food Systems: Concepts, Impacts, and Issues. Washington, DC: United States Department of Agriculture, Economic Research Service, Economic Research Report Number 97, 2010. Internet site: https://www.ers.usda.gov/webdocs/publications/46393/7054_err97_1_.pdf?v=9850.4 (Accessed August 7, 2015).

McCutcheon, E., J. Bruwer, and E. Li. "Region of Origin and Its Importance Among Choice Factors in the Wine-Buying Decision Making of Consumers." International Journal of Wine Business Research 21,3(2009):212-34.

Meas, T., W. Hu, M.T. Batte, T.A. Woods, and S. Ernst. "Substitutes or Complements? Consumer Preference for Local and Organic Food Attributes." American Journal of Agricultural Economics 97,4(2015):1044-71.

Mendelson, R. Appellation Napa Valley: Building and Protecting an American Treasure. Napa Valley: Val de Grace, 2016.

Munsie, J. “A Brief History of the International Regulation of Wine Production,” 2002. Internet site: https://nrs.harvard.edu/ urn-3:HUL.InstRepos:8944668 (Accessed April 2, 2019).

Oczkowski, E. “A Hedonic Price Function for Australian Premium Table Wine.” Australian Journal of Agricultural Economics 38,1(1994):93-110.

Office of the Federal Register. "Establishment of the Outer Coastal Plain Viticultural Area (2003R-166P)," 2007. Internet site: https://www.federalregister.gov/documents/2007/02/09/07-575/establishment-of-the-outer-coastal-plain-viticultural-area2003r-166p (Accessed May 21, 2018). 
Office of the Federal Register. "Part 9-American Viticultural Areas." Internet site: https://www.ecfr.gov/cgi-bin/ retrieveECFR? $n=$ pt27.1.9 (Accessed December 10, 2018).

Orth, U.R., M. McGarry Wolf, and T.H. Dodd. "Dimensions of Wine Region Equity and Their Impact on Consumer Preferences." Journal of Product \& Brand Management 14,2(2005):88-97.

Ostrom, E. "A Behavioral Approach to the Rational Choice Theory of Collective Action: Presidential Address, American Political Science Association, 1997.” The American Political Science Review 92,1(1998):1-22.

Outer Coastal Plain Vineyard Association. "Grape Varieties." Internet site: https://www.outercoastalplain.com/ ocpva_varieties.cfm (Accessed June 23, 2020).

Perrouty, J.P., F. d'Hauteville, and L. Lockshin. "The Influence of Wine Attributes on Region of Origin Equity: An Analysis of the Moderating Effect of Consumer's Perceived Expertise." Agribusiness 22,3(2006):323-41.

Puckette, M. "Looking for Good Wine? Start with the Appellation," Wine Folly, 2015. Internet site: https://winefolly.com/ review/looking-for-good-wine-start-with-the-appellation/ (Accessed October 5, 2018).

Puckette, M. "Decoding French Wine Labels and Terms," Wine Folly, 2016. Internet site: https://winefolly.com/review/ french-wine-labels-and-terms/ (Accessed October 5, 2018).

Quackenbush, J. “U.S. Wine Tops \$10-a-bottle Average for First Time, Expert Says," North Bay Business Journal, 2017. Internet site: http://www.northbaybusinessjournal.com/northbay/sonomacounty/6588305-181/us-wine-tops-10-a-bottleaverage (Accessed May 25, 2019).

Qualtrics. Internet site: https://www.qualtrics.com/research-core/survey-software/ (Accessed August 12, 2019).

Quandt, R.E., G.M. Taber, R.E. Quandt, G.M. Taber, and R.E. Quandt. "Comments on the Judgment of Princeton." Journal of Wine Economics 7,2(April 2012):152-4.

Ryan, C., and K. Bauman. "Educational Attainment in the United States: 2015," 2016. Washington, DC: U.S. Census Bureau. Internet site: https:/www.census.gov/content/dam/Census/library/publications/2016/demo/p20-578.pdf (Accessed June 4, 2017).

Sawyer, A.G. "Demand Artifacts in Laboratory Experiments in Consumer Research." Journal of Consumer Research 1,4(1975):20-30.

Schamel, G. "Dynamic Analysis of Brand and Regional Reputation: The Case of Wine." Journal of Wine Economics 4,1(2009):62-80.

Smith, R. “The Trick To Selling Fancy Wine From New Jersey: Don't Say It's From New Jersey,” Planet Money, 2013. Internet site: https://www.npr.org/sections/money/2013/03/29/175603136/the-trick-to-selling-fancy-wine-from-new-jersey-dontsay-its-from-new-jersey (Accessed December 18, 2018).

Sogari, G., C. Corbo, M. Macconi, D. Menozzi, and C. Mora. “Consumer Attitude Towards Sustainable-Labelled Wine: An Exploratory Approach.” International Journal of Wine Business Research 27,4(2015):312-28.

Sogari, G., C. Mora, and D. Menozzi. "Sustainable Wine Labeling: A Framework for Definition and Consumers' Perception." Agriculture and Agricultural Science Procedia 8(2016):58-64.

Statista. "Total Number of Wineries in the U.S. from 2009 to 2019." Internet site: https://www.statista.com/statistics/259353/ number-of-wineries-in-the-us/ (Accessed March 7, 2019).

Steenkamp, J.-B.E.M. “Conceptual Model of the Quality Perception Process.” Journal of Business Research 21,4(1990):309-33.

Taber, G.M. Judgment of Paris. New York: Simon and Schuster, 2006.

Thach, L. “The State of Wine Drinking in America Today," The Week, 2015. Internet site: http://theweek.com/articles/532653/ state-winedrinking-america-today (Accessed July 6, 2017).

Thach, L., and A. Camillo. “A Snapshot of the American Wine Consumer in 2018," Wine Business, 2018. Internet site: https:// www.winebusiness.com/news/?go=getArticle\&dataId=207060 (Accessed June 23, 2020).

Thompson, L. "How New Jersey is Producing Some of the Best Wines in the East," Wine Enthusiast, 2018. Internet site: https://www.winemag.com/2018/04/03/new-jersey-bottles-wines/ (Accessed June 23, 2020).

Tonsor, G.T., and R.S. Shupp. "Cheap Talk Scripts and Online Choice Experiments: Looking Beyond the Mean." American Journal of Agricultural Economics 93,4(2011):1015-31.

Train, K. Discrete Choice Methods with Simulation. New York: Cambridge University Press, 2003.

Tversky, A., and D. Kahneman. “Advances in Prospect Theory: Cumulative Representation of Uncertainty.” Journal of Risk and Uncertainty 5,4(1992):297-323.

Uchida, H., C.A. Roheim, H. Wakamatsu, and C.M. Anderson. "Do Japanese Consumers Care About Sustainable Fisheries? Evidence from an Auction of Ecolabelled Seafood." Australian Journal of Agricultural and Resource Economics 58,2(2013):263-280.

United States Census Bureau. "Income and Poverty in the United States: 2016," 2017. Internet site: https://www.census.gov/ data/tables/2017/demo/income-poverty/p60-259.html (Accessed August 18, 2018).

U.S. Department of the Treasury. "Wine Statistics." Internet site: https://www.ttb.gov/wine/wine-stats.shtml (Accessed December 11, 2018b).

U.S. Department of the Treasury. Internet site: https://www.ttb.gov/regulation_guidance/ablapenalty.shtml (Accessed December 11, 2018c).

U.S. Department of the Treasury. Internet site: https://www.ttb.gov/wine/us_by_ava.shtml (Accessed December 11, 2018a). 
Waldrop, M.E., J.J. McCluskey, and R.C. Mittelhammer. "Products with Multiple Certifications: Insights from the US Wine Market." European Review of Agricultural Economics 44,4(2017):658-82.

Walker, J. "Mixed Logit (Or Logit Kernel) Model: Dispelling Misconceptions of Identification.” Transportation Research Record 1805,1(2002):86-98.

wine-searcher.com. Internet site: https://www.wine-searcher.com/most-expensive-wines.lml (Accessed December 5, 2018). Wine \& Vines. 2017. Internet site: http://www.winesandvines.com/news/179571 (Accessed June 4, 2018).

Wine Intelligence. "US Portraits 2018," 2018. Internet site: https://www.wineintelligence.com/downloads/us-portraits-2018/ (Accessed June 23, 2020).

\section{Appendix}

Table A1. ML model with New Jersey residents interaction terms

\begin{tabular}{|c|c|c|c|}
\hline & Coefficients & Standard error & $P$ value \\
\hline Price & -0.226 & 0.008 & 0.000 \\
\hline Opt out & -4.509 & 0.172 & 0.000 \\
\hline Organic & 0.254 & 0.057 & 0.000 \\
\hline Sustainable & 0.045 & 0.047 & 0.339 \\
\hline NJ & -0.274 & 0.091 & 0.003 \\
\hline Pilesgrove & -0.264 & 0.080 & 0.001 \\
\hline California & 0.794 & 0.072 & 0.000 \\
\hline Napa & 1.056 & 0.083 & 0.000 \\
\hline USA & 0.293 & 0.072 & 0.000 \\
\hline \multicolumn{4}{|c|}{ Interaction terms with New Jersey Residents } \\
\hline$N J^{\star} N J R$ & 1.168 & 0.752 & 0.121 \\
\hline$O C P^{\star} N J R$ & 0.156 & 0.646 & 0.809 \\
\hline Pilesgrove*NJR & 0.430 & 0.690 & 0.533 \\
\hline California*NJR & -0.066 & 0.642 & 0.918 \\
\hline Napa*NJR & 0.044 & 0.630 & 0.944 \\
\hline USA*NJR & -0.179 & 0.669 & 0.789 \\
\hline \multicolumn{4}{|c|}{ [Cholesky matrix output omitted] } \\
\hline Log-likelihood & & $-6,796.27$ & \\
\hline McFadden $R^{2}$ & & 0.2614 & \\
\hline
\end{tabular}

Note: NJR denotes New Jersey Residents.

Cite this article: Lim KH (2021). Sounds Better? Potential Implications of Obscure American Viticultural Areas to Consumers. Journal of Agricultural and Applied Economics 53, 37-54. https://doi.org/10.1017/aae.2020.27 